\title{
Catalytic synthesis of nitrogen-doped multi-walled carbon nanotubes using layered double hydroxides as catalyst precursors
}

\author{
YONG CAO, YUN ZHAO, QINGXIA LI and QINGZE JIAO* \\ School of Chemical Engineering and the Environment, Beijing Institute of Technology, \\ Beijing 100081, PR China \\ e-mail: jiaoqz@bit.edu.cn
}

MS received 22 January 2008; revised 15 November 2008

\begin{abstract}
The nitrogen $(\mathrm{N})$-doped carbon $\left(\mathrm{CN}_{\mathrm{x}}\right)$ nanotubes were synthesized by pyrolysis of ethylenediamine with $\mathrm{Ni}_{1.07} \mathrm{Mg}_{1.01} \mathrm{AlO}_{3.58}, \mathrm{Ni}_{1.99} \mathrm{Mg}_{0.29} \mathrm{AlO}_{3.78}$, and $\mathrm{Ni}_{2.31} \mathrm{Mg}_{0.08} \mathrm{AlO}_{3.89}$ mixed oxides as catalysts at $650^{\circ} \mathrm{C}$. Those mixed oxides were obtained by calcination of corresponding layered double hydroxide precursors (LDHs). Structure and composition of LDHs and mixed oxides were characterized by X-ray diffraction (XRD) and Inductively coupled plasma spectrum. X-ray photoelectron spectroscopy and transmission electron microscope were used to characterize the $\mathrm{N}$ content, proportion of pyridine-like $\mathrm{N}$ structure and morphology of $\mathrm{CN}_{x}$ nanotubes. The results showed that the tubes grown with $\mathrm{Ni}_{2.31} \mathrm{Mg}_{0.08} \mathrm{AlO}_{3.89}$ as catalysts had more obvious bamboo-like structure, larger diameter than those grown with $\mathrm{Ni}_{1.07} \mathrm{Mg}_{1.01} \mathrm{AlO}_{3.58}$ and $\mathrm{Ni}_{1.99} \mathrm{Mg}_{0.29} \mathrm{AlO}_{3.78}$. The $\mathrm{N}$ content and proportion of graphitic-like $\mathrm{N}$ structures increased with the content of $\mathrm{Ni}^{2+}$ increasing in LDH precursors. The morphology, $\mathrm{N}$ content and pyridine-like $\mathrm{N}$ structures for $\mathrm{CN}_{x}$ nanotubes can be controlled to a certain extent by varying the content of $\mathrm{Ni}^{2+}$ in $\mathrm{LDH}$ precursors.
\end{abstract}

Keywords. Layered double hydroxides; N-doped carbon nanotube; pyrolysis; catalyst.

\section{Introduction}

Layered double hydroxides (LDHs) are composed of charged brucite-like layers of divalent and trivalent metal hydroxides, whose excess positive charge due to the incorporated trivalent metal cation is balanced by anions in the interlayer. LDHs themselves have attracted a great deal of interest as anion exchangers, adsorbents, ionic conductors and antacids ${ }^{1}$. Furthermore, the mixed oxides obtained by calcination of LDHs at intermediate temperatures $\left(450-600^{\circ} \mathrm{C}\right)$ are of considerable interest in their own right as catalysts and catalyst supports ${ }^{1}$. Various transition metal cations introduced into the brucite-like layers of LDHs can be precursors of redox-type centers, showing attractive catalytic activity due to the novel properties of the final catalysts, such as high metal dispersion. Yun Zhao has synthesized the carbon nanosturctures (nanofibres, single-walled and multiwalled carbon nanotubes) using the mixed oxides of $\mathrm{Fe}_{0.1} \mathrm{Mg}_{2} \quad \mathrm{Al}_{0.9} \mathrm{O}_{3.45}, \quad \mathrm{Fe}_{0.1} \mathrm{Zn}_{2} \mathrm{Al}_{0.9} \mathrm{O}_{3.45}$ and $\mathrm{Fe}_{0.1}$ $\mathrm{Cu}_{2} \mathrm{Al}_{0.9} \mathrm{O}_{3.45}$ by calcination of their corresponding $\mathrm{LDH}$ precursors as catalysts at $910^{\circ} \mathrm{C} .^{2}$

\footnotetext{
*For correspondence
}

Carbon nanotubes (CNTs) are currently attractive materials for a diverse range of applications because of their extraordinary mechanical and electrical properties. ${ }^{3}$ The important potential applications include field emission displays ${ }^{4}$ and nanoscale electronic devices. ${ }^{5,6}$ Many of these applications are based on the electrical properties of CNTs, which strongly depend on their helicity and diameter. ${ }^{7}$ Therefore, the control of electrical properties is very important in many applications of CNTs.

Synthesis of $\mathrm{N}$-doped carbon $\left(\mathrm{CN}_{x}\right)$ nanotubes has recently been considered as a possible method to control the electrical properties of CNTs in a welldefined way. An enhancement of conductivity is expected, because the additional electrons contributed by the $\mathrm{N}$ atom provide electron carriers for the conduction band. ${ }^{8}$ The advantage of such nanotubes is that their conductive properties are primarily determined by the composition and are thus relatively easy to control. $\mathrm{CN}_{x}$ nanotubes are mainly prepared by chemical vapour deposition (CVD), arc discharge, and magnetron sputtering. CVD is considered as the best method for a large-scale production of CNTs. Many research groups have produced $\mathrm{CN}_{x}$ nanotubes 
by CVD using $\mathrm{C} / \mathrm{N}$ sources. ${ }^{9-13}$ However, almost all the catalysts used to grow $\mathrm{CN}_{x}$ nanotubes are focused on iron, such as ferrocene, ${ }^{9}$ iron phthalocyanine, ${ }^{10}$ iron oxide film, ${ }^{11}$ and iron film. ${ }^{12}$ Nickel catalysts are rarely investigated excepting for $\mathrm{Ni}$ phthalocyanine $\left(\mathrm{NiC}_{32} \mathrm{~N}_{8} \mathrm{H}_{16}\right)$.

$\mathrm{CN}_{x}$ nanotubes synthesized by pyrolyzing $\mathrm{NiC}_{32} \mathrm{~N}_{8} \mathrm{H}_{16}$ as a staring material has been reported. ${ }^{14,15}$ However, it always requires high purity $\mathrm{NiC}_{32} \mathrm{~N}_{8} \mathrm{H}_{16}$ and a dual furnace fitted with independent temperature controllers. One heating stage is used to evaporate $\mathrm{NiC}_{32} \mathrm{~N}_{8} \mathrm{H}_{16}$ and the other stage is used to pyrolyze $\mathrm{NiC}_{32} \mathrm{~N}_{8} \mathrm{H}_{16}$ to generate the $\mathrm{Ni}$ atoms or clusters deposited on the substrate to grow tubes. Another disadvantage is that the growth temperature is required above $800^{\circ} \mathrm{C}$. Previous report ${ }^{14}$ showed that CNTs could not be synthesized using $\mathrm{NiC}_{32} \mathrm{~N}_{8} \mathrm{H}_{16}$ at the temperatures below $800^{\circ} \mathrm{C}$.

In this paper, we synthesized the $\mathrm{CN}_{\mathrm{x}}$ nanotubes by a simple CVD using the mixed oxides containing $\mathrm{Ni}$ as catalysts only at $650^{\circ} \mathrm{C}$. The lower growth temperature facilitates to form the pyridine-like $\mathrm{N}$ structures, which are responsible for the metallic properties of the $\mathrm{CN}_{x}$ nanotubes. ${ }^{8}$ The influence of the content of $\mathrm{Ni}^{2+}$ in LDHs on the doped $\mathrm{N}$ content and morphology of $\mathrm{CN}_{x}$ nanotubes were investigated.

\section{Experimental}

\subsection{Preparation and calcination of $L D H s$}

LDHs with various $\mathrm{Ni}$ content were prepared using a coprecipitaion reaction. A $100 \mathrm{~mL}$ solution containing $\mathrm{Ni}\left(\mathrm{NO}_{3}\right)_{2} \cdot 6 \mathrm{H}_{2} \mathrm{O}, \mathrm{Mg}\left(\mathrm{NO}_{3}\right)_{2} \cdot 6 \mathrm{H}_{2} \mathrm{O}$, and $\mathrm{Al}\left(\mathrm{NO}_{3}\right)_{3}$. $9 \mathrm{H}_{2} \mathrm{O}([\mathrm{Ni}+\mathrm{Mg}] / \mathrm{Al}=2 \cdot 5 / 1$ (molar ratio)) was added, slowly and with vigorous stirring, to another $100 \mathrm{~mL}$ solution with $\mathrm{NaOH}$ and $\mathrm{Na}_{2} \mathrm{CO}_{3}$. The resulting slurry was aged at $90^{\circ} \mathrm{C}$. The final precipitate was filtered, washed thoroughly with water and dried. Varying the $\mathrm{Ni}\left(\mathrm{NO}_{3}\right)_{2} \cdot 6 \mathrm{H}_{2} \mathrm{O}$ and $\mathrm{Mg}\left(\mathrm{NO}_{3}\right)_{2} \cdot 6 \mathrm{H}_{2} \mathrm{O}$ content in the solution of nitrates, LDHs with various $\mathrm{Ni}$ content were obtained. The mixed oxides were obtained by calcination of $\mathrm{LDH}$ precursors at $600^{\circ} \mathrm{C}$ in air.

\subsection{Synthesis of $C N_{x}$ nanotubes}

Synthesis of $\mathrm{CN}_{x}$ nanotubes was carried out in a horizontal furnace. The mixed oxide catalyst $(0.50 \mathrm{~g})$ was transferred to a quartz boat and placed in the middle of furnace, which was heated under a flowing $\operatorname{Ar}(200 \mathrm{~mL} / \mathrm{min})$ at a rate of $5 \mathrm{~K} / \mathrm{min}$. On reach- ing $400^{\circ} \mathrm{C}$, Ar was switched to $\mathrm{H}_{2}(120 \mathrm{sccm})$ to reduce the mixed metal oxide. On reaching $650^{\circ} \mathrm{C}$, ethylenediamine was pumped into the furnace at a rate of $0.3 \mathrm{~mL} / \mathrm{min}$. The reaction was maintained for $40 \mathrm{~min}$, after which the furnace was allowed to cool to room temperature under $\mathrm{Ar}$. $\mathrm{CN}_{x}$ nanotubes were purified by immersing the as-prepared products in a nitric acid solution for $24 \mathrm{~h}$.

\subsection{Characterization techniques}

The catalysts were characterized by X-ray diffraction (XRD) and inductively coupled plasma spectrum (ICP). The XRD patterns were determined using a X'PERT PRO MPD X-ray diffractometer, using $\mathrm{CuK} \alpha \mathrm{l}$ radiation. The generator tension was $40 \mathrm{kV}$ and the generator current was $40 \mathrm{~mA}$. ICP was recorded on a ULTIMA instrument. The samples were dissolved by nitric acid.

Transmission electron microscope (TEM), X-ray photoelectron spectroscopy (XPS), and Raman spectroscopy were used to characterize the purified tubes. The morphology of $\mathrm{CN}_{\mathrm{x}}$ nanotubes was examined by TEM using a JEM-1200EX electron microscope. Purified $\mathrm{CN}_{x}$ nanotubes were suspended in ethanol and a drop of the suspension was deposited on a copper grid and the solvent was evaporated. Micrographs were taken at $100 \mathrm{kV}$. The content and the structure of $\mathrm{N}$ in $\mathrm{CN}_{x}$ nanotubes was determined by XPS (Physical electronics PHI 5300) using a vacuum generators XPS system operating with $\mathrm{Mg}$ $(\mathrm{K} \alpha)$ radiation. The raw data were correcting for charging using the binding energy of graphite at $284.6 \mathrm{eV}$. Peak areas were determined after back ground subtraction using Shirley's method and fitting the spectra with Gaussian curves. The content of N incorporated was calculated from the peak areas of the Cls and N1s peaks after correcting for differences in sensitivity using sensitivity factors of 0.25 and 0.42 for $\mathrm{C}$ and $\mathrm{N}$, respectively. Raman spectroscopy was carried out on Renishaw inVia-Reflex instrument using the excitation wavelength of $532 \mathrm{~nm}$.

\section{Results and discussion}

\subsection{ICP and XRD characterization of the catalysts}

ICP was employed to measure the metal composition of the prepared LDHs. The results are $\mathrm{Ni}_{1.07}$ $\mathrm{Mg}_{1.01} \mathrm{Al}-\mathrm{LDH}, \mathrm{Ni}_{1.99} \mathrm{Mg}_{0.29} \mathrm{Al}-\mathrm{LDH}$, and $\mathrm{Ni}_{2 \cdot 31} \mathrm{Mg}_{0.08}$ Al-LDH, respectively. Powder XRD patterns for asprepared $\mathrm{Ni}_{1.07} \mathrm{Mg}_{1.01} \mathrm{Al}-\mathrm{LDH}, \mathrm{Ni}_{1.99} \mathrm{Mg}_{0.29} \mathrm{Al}-\mathrm{LDH}$, 
and $\mathrm{Ni}_{2.31} \mathrm{Mg}_{0.08} \mathrm{Al}-\mathrm{LDH}$ are shown in figure 1. In each case, the XRD pattern exhibits the characteristic reflections of an LDH material, which shows that it contains hydrotalcite as the main component, exhibiting sharp and symmetric reflections for the basal (003), (006), and (009). The basal spacing obtained from the $d_{003}$ is $0.758,0.778$, and $0.789 \mathrm{~nm}$ for asprepared $\mathrm{Ni}_{1.07} \mathrm{Mg}_{1.01} \mathrm{Al}-\mathrm{LDH}, \mathrm{Ni}_{1.99} \mathrm{Mg}_{0.29} \mathrm{Al}-\mathrm{LDH}$, and $\mathrm{Ni}_{2 \cdot 31} \mathrm{Mg}_{0.08} \mathrm{Al}-\mathrm{LDH}$.

The above $\mathrm{LDH}$ samples were calcined at $600^{\circ} \mathrm{C}$ for $4 \mathrm{~h}$ to obtain catalysts used to grow $\mathrm{CN}_{\mathrm{x}}$ nanotubes. The powder XRD patterns for the calcined

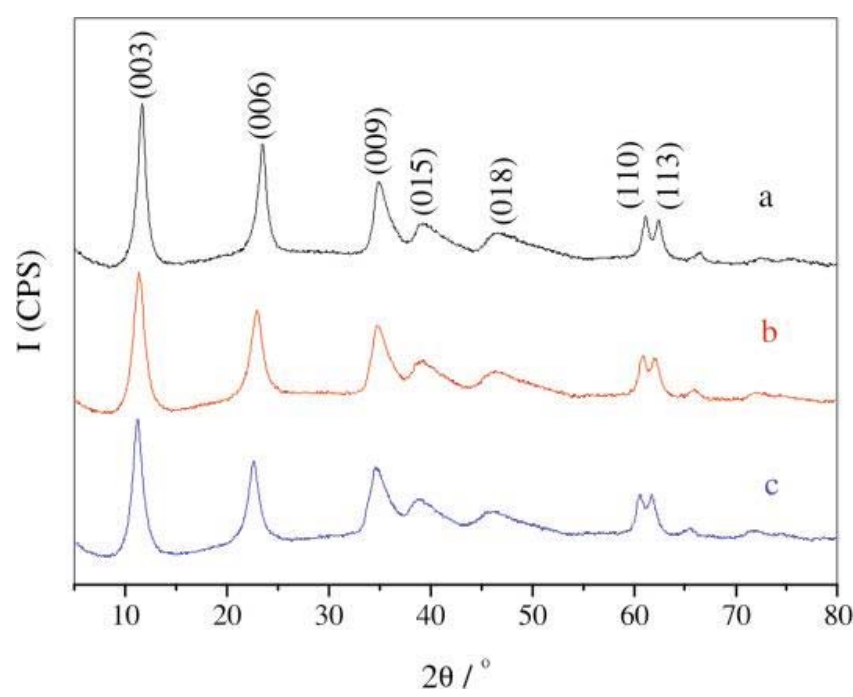

Figure 1. XRD patterns for LDHs with different components: (a) $\mathrm{Ni}_{1.07} \mathrm{Mg}_{1 \cdot 01} \mathrm{Al}-\mathrm{LDH}$, (b) $\mathrm{Ni}_{1.99} \mathrm{Mg}_{0.29} \mathrm{Al}-\mathrm{LDH}$ and (c) $\mathrm{Ni}_{2 \cdot 31} \mathrm{Mg}_{0.08} \mathrm{Al}-\mathrm{LDH}$.

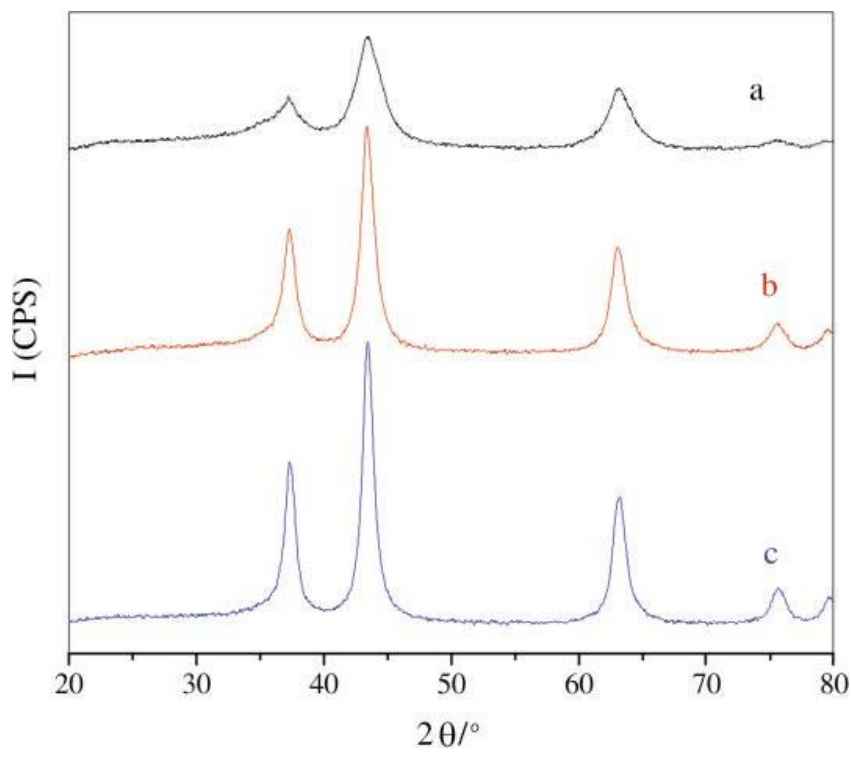

Figure 2. XRD patterns for mixed oxides obtained by calcination of different LDH precursors: (a) $\mathrm{Ni}_{1.07} \mathrm{Mg}_{1.01}$ $\mathrm{AlO}_{3.58}$, (b) $\mathrm{Ni}_{1.99} \mathrm{Mg}_{0.29} \mathrm{AlO}_{3.78}$ (c) $\mathrm{Ni}_{2.31} \mathrm{Mg}_{0.08} \mathrm{AlO}_{3.89}$. products from the LDH precursors are shown in figure 2. For $\mathrm{Ni}_{1.07} \mathrm{Mg}_{1.01} \mathrm{AlO}_{3.58}, \mathrm{Ni}_{1.99} \mathrm{Mg}_{0.29} \mathrm{AlO}_{3.78}$ and $\mathrm{Ni}_{2.31} \mathrm{Mg}_{0.08} \mathrm{AlO}_{3.89}$ samples, XRD patterns show the diffraction peaks of MgO (JCPDS 4520946) and NiO (JCPDS 4721049), which overlap each other. The peaks are broad because of the low crystallinity. This indicates that the calcined products of LDHs are mixed oxides with an $\mathrm{MgO}$-like structure (for $\mathrm{Ni}_{1.07} \mathrm{Mg}_{1.01} \mathrm{AlO}_{3.58}$ ) or a NiO-like (for $\mathrm{Ni}_{1.99} \mathrm{Mg}_{0.29}$ $\mathrm{AlO}_{3.78}$ and $\mathrm{Ni}_{2.31} \mathrm{Mg}_{0.08} \mathrm{AlO}_{3.89}$ ) structure as reported by Yun Zhao et al. ${ }^{16}$

\subsection{TEM, XPS, and Raman characterization of $C N_{x}$ nanotubes}

TEM images of $\mathrm{CN}_{\mathrm{x}}$ nanotubes prepared with various catalysts are shown in figure 3 . The diameter of the tubes grown with $\mathrm{Ni}_{1.07} \mathrm{Mg}_{1.01} \mathrm{AlO}_{3.58}$ and $\mathrm{Ni}_{1.99}$ $\mathrm{Mg}_{0.29} \mathrm{AlO}_{3.78}$ are about $15-50 \mathrm{~nm}$, while the other grown with $\mathrm{Ni}_{2 \cdot 31} \mathrm{Mg}_{0.08} \mathrm{AlO}_{3.89}$ are about $15-80 \mathrm{~nm}$. Almost all the tubes grown with $\mathrm{Ni}_{2 \cdot 31} \mathrm{Mg}_{0.08} \mathrm{AlO}_{3.89}$ have an obvious bamboo-like morphology with transverse carbon bridges forming compartments, similar to other reported structures of $\mathrm{CN}_{x}$ nanotubes. ${ }^{9-13}$ But for the tubes grown with $\mathrm{Ni}_{1.07}$ $\mathrm{Mg}_{1.01} \mathrm{AlO}_{3.58}$ and $\mathrm{Ni}_{1.99} \mathrm{Mg}_{0.29} \mathrm{AlO}_{3.78}$, the bamboolike morphology is unconspicuous. In addition, the compartment layers of the tubes grown with $\mathrm{Ni}_{2.31}$ $\mathrm{Mg}_{0.08} \mathrm{AlO}_{3.89}$ are thicker and the distance between two adjacent layers becomes longer than those grown with $\mathrm{Ni}_{1.07} \mathrm{Mg}_{1.01} \mathrm{AlO}_{3.58}$ and $\mathrm{Ni}_{1.99} \mathrm{Mg}_{0.29} \mathrm{AlO}_{3.78}$.

XPS analysis was carried out on the $\mathrm{CN}_{x}$ nanotubes grown with various catalysts to look for the content and the structure of $\mathrm{N}$ in each product. The $\mathrm{C} 1 \mathrm{~s}$ and N1s XPS spectra of $\mathrm{CN}_{x}$ nanotubes are shown in figure 4(A) and (B), respectively. All XPS spectra show that the tubes consist of carbon accompanied by traces of $N$. The $\mathrm{N}$ content, which is defined as the $N /(N+C)$ atomic ratio\%, was estimated by the area ration of the $\mathrm{C} 1 \mathrm{~s}$ and N1s peaks, taking into consideration of their relative sensitivities.

For all XPS spectra, the asymmetric $\mathrm{Cls}$ band and N1s band can be observed centered at $284.6 \mathrm{eV}$ and $400.5 \mathrm{eV}$ respectively. From the curve fitting, the N1s band can be deconvoluted into two bands at around $399.5 \mathrm{eV}(\mathrm{PN} 1)$ and $401.6 \mathrm{eV}$ (PN2). The PN1 and PN2 correspond to pyridine-like and graphitic-like $\mathrm{N}^{11,17}$ The pyridine-like $\mathrm{N}$ is referred to the $\mathrm{N}$ atoms that contribute to the system with a pair of pi electrons, whereas graphitic-like $\mathrm{N}$ 

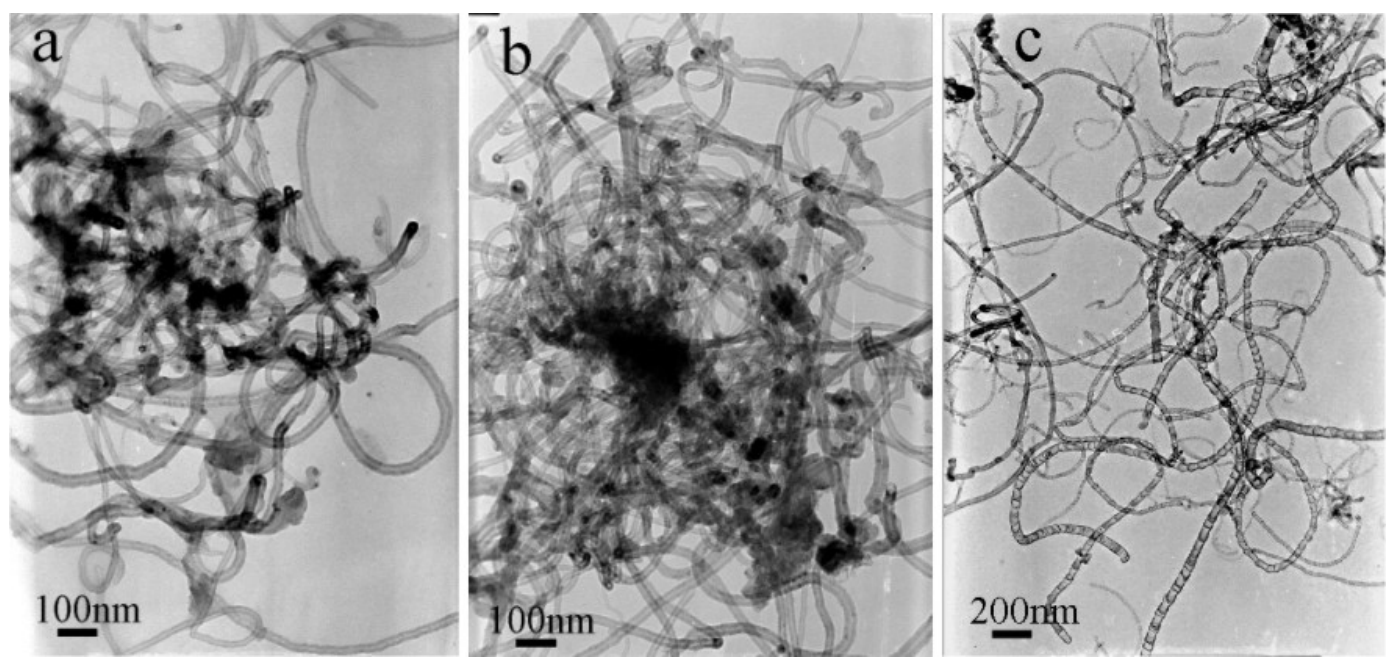

Figure 3. TEM micrographs for products with various catalysts: (a) $\mathrm{Ni}_{1.07} \mathrm{Mg}_{1.01} \mathrm{AlO}_{3.58}$, (b) $\mathrm{Ni}_{1.99} \mathrm{Mg}_{0.29} \mathrm{AlO}_{3.78}$ (c) $\mathrm{Ni}_{2.31} \mathrm{Mg}_{0.08} \mathrm{AlO}_{3.89}$.

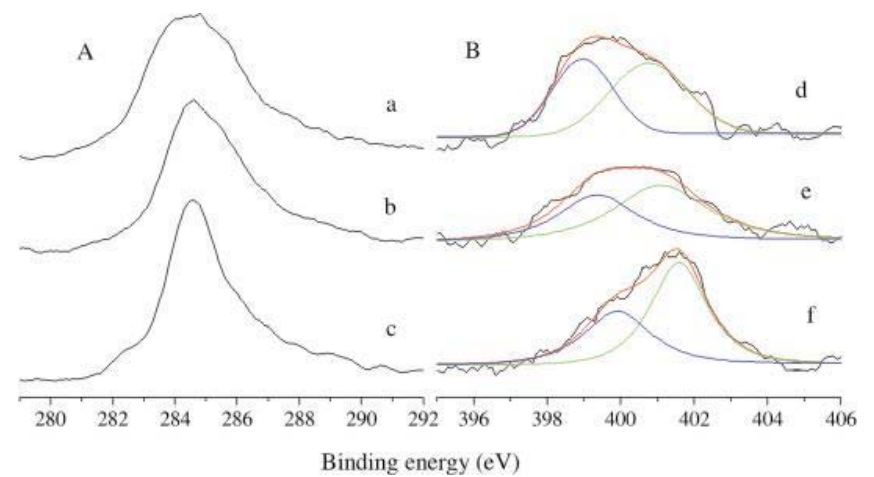

Figure 4. $\mathrm{Cls}(\mathbf{A})$ and N1s (B) XPS spectra of the $\mathrm{CN}_{x}$ nanotubes grown with various catalysts: (a), (d) $\mathrm{Ni}_{1.07}$ $\mathrm{Mg}_{1.01} \mathrm{AlO}_{3.58} ;$ (b), (e) $\mathrm{Ni}_{1.99} \mathrm{Mg}_{0.29} \mathrm{AlO}_{3.78}$, (c), (f), $\mathrm{Ni}_{2.31}$ $\mathrm{Mg}_{0.08} \mathrm{AlO}_{3.89}$.

Table 1. The $\mathrm{N}$ content and the intensity of PN1 and PN2 structures for all the grown $\mathrm{CN}_{\mathrm{x}}$ nanotubes with various catalysts.

\begin{tabular}{lccc}
\hline & & \multicolumn{2}{c}{$\begin{array}{c}\text { The intensity of different } \\
\text { N Structures (\%) }\end{array}$} \\
\cline { 3 - 4 } Catalyst & $\begin{array}{c}\text { N content } \\
\text { (at.\%) }\end{array}$ & PN1 & PN2 \\
\hline $\mathrm{Ni}_{1.07} \mathrm{Mg}_{1.01} \mathrm{AlO}_{3.58}$ & 5.4 & 46 & 54 \\
$\mathrm{Ni}_{1.99} \mathrm{Mg}_{0.29} \mathrm{AlO}_{3.78}$ & 6.6 & 42 & 58 \\
$\mathrm{Ni}_{2.31} \mathrm{Mg}_{0.08} \mathrm{AlO}_{3.89}$ & $8 \cdot 8$ & 38 & 62 \\
\hline
\end{tabular}

corresponds to the coordinated $\mathrm{N}$ atoms substituting for $\mathrm{C}$ atoms in the graphene layers. ${ }^{13}$ There are several ways in which $\mathrm{N}$ can be incorporated in the CNT lattice ${ }^{18}$. However, there are only two ways observed in our studies as others have reported. ${ }^{11,17,19}$ The N content and intensity of PN1 and PN2 struc- tures are listed in table 1. For catalysts with various $\mathrm{Ni}^{2+}$ content, the higher $\mathrm{Ni}^{2+}$ content, the higher $\mathrm{N}$ content and proportion of graphitic-like $\mathrm{N}$ structures can be obtained in the grown tubes.

We note that the tube morphology depends strongly on the $\mathrm{N}$ content. The tubes grown with $\mathrm{Ni}_{2 \cdot 31} \mathrm{Mg}_{0.08}$ $\mathrm{AlO}_{3.89}$ have the $\mathrm{N}$ content of 8.8 at. $\%$ and all have an obvious bamboo-like morphology. However, an unconspicuous bamboo-like morphology exists in the tubes grown with $\mathrm{Ni}_{1.07} \mathrm{Mg}_{1.01} \mathrm{AlO}_{3.58}$ and $\mathrm{Ni}_{1.99}$ $\mathrm{Mg}_{0.29} \mathrm{AlO}_{3.78}$, which have the $\mathrm{N}$ content of 5.4 and 6.6 at. \%. So we can conclude that the higher $\mathrm{N}$ content, the more compartmentalized of tubes become, which is consistent with the early report. ${ }^{10}$ The higher $\mathrm{N}$ content also leads to the compartment layers in the tubes grown with $\mathrm{Ni}_{2.31} \mathrm{Mg}_{0.08} \mathrm{AlO}_{3.89}$ becoming thicker and the distance between two adjacent compartment layers becoming longer. During the tube growing process, the compartment layers were bent and connected with the wall under less strain for the higher $\mathrm{N}$ content. After the joint, the sheets of compartment layers would grow eventually depart from the catalytic particles. If the stress were release, this joint growth would take longer before departing from the catalytic particle, resulting in less frequent formation of the thicker compartment layers. ${ }^{20}$

The Raman spectra of the $\mathrm{CN}_{x}$ nanotubes with various catalysts are shown in figure 5. All spectra show mainly two bands at $\sim 1351 \mathrm{~cm}^{-1}$ (D-band) and $\sim 1580 \mathrm{~cm}^{-1}$ (G-band). The $\mathrm{G}$ band originates from the Raman active $E_{2 g}$ mode due to in-plane atomic displacements. The origin of $\mathrm{D}$ band has been explained as disorder-induced features due to the finite particle size effect or lattice distortion. ${ }^{20}$ As the con- 


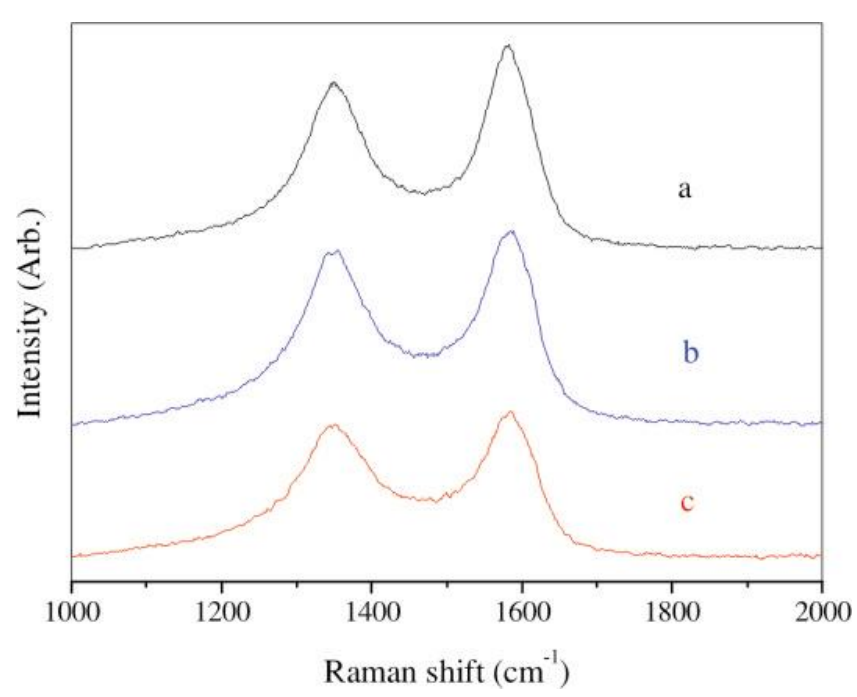

Figure 5. Raman spectrum for products with various catalysts: (a) $\mathrm{Ni}_{1.07} \mathrm{Mg}_{1.01} \mathrm{AlO}_{3.58}$, (b) $\mathrm{Ni}_{1.99} \mathrm{Mg}_{0.29} \mathrm{AlO}_{3.78}$ (c) $\mathrm{Ni}_{2.31} \mathrm{Mg}_{0.08} \mathrm{AlO}_{3.89}$.

tent of $\mathrm{Ni}^{2+}$ in catalyst increases from $\mathrm{Ni}_{1.07} \mathrm{Mg}_{1.01}$ $\mathrm{AlO}_{3.58}$ to $\mathrm{Ni}_{2.31} \mathrm{Mg}_{0.08} \mathrm{AlO}_{3.89}$, the $I_{\mathrm{D}} / I_{\mathrm{G}}$ value increase from 1.26 to 1.63 . For the $\mathrm{CN}_{x}$ tubes grown with $\mathrm{Ni}_{1.99} \mathrm{Mg}_{0.29} \mathrm{AlO}_{3 \cdot 78}$, the $I_{\mathrm{D}} / I_{\mathrm{G}}$ value is 1.47 . This suggests that more defects and disorders are introduced as the content of $\mathrm{Ni}^{2+}$ in catalyst increases. Based on the experimental results, it is believed that the defects and disorders are related to the presence of $\mathrm{N}$ in the $\mathrm{CN}_{x}$ tubes.

\section{Conclusions}

$\mathrm{Ni}_{1.07} \mathrm{Mg}_{1.01} \mathrm{Al}-\mathrm{LDH}, \mathrm{Ni}_{1.99} \mathrm{Mg}_{0.29} \mathrm{Al}-\mathrm{LDH}$, and $\mathrm{Ni}_{2.31}$ $\mathrm{Mg}_{0.08} \mathrm{Al}-\mathrm{LDH}$ were prepared by introducing $\mathrm{Ni}^{2+}$ into the $\mathrm{LDH}$ layers. The $\mathrm{CN}_{x}$ nanotubes were synthesized using $\mathrm{Ni}_{1.07} \mathrm{Mg}_{1.01} \mathrm{AlO}_{3.58}, \mathrm{Ni}_{1.99} \mathrm{Mg}_{0.29} \mathrm{AlO}_{3.78}$, and $\mathrm{Ni}_{2.31} \mathrm{Mg}_{0.08} \mathrm{AlO}_{3.89}$ mixed oxides as catalysts obtained by calcination of these LDH precursors. By control the content of $\mathrm{Ni}^{2+}$ in LDHs, the $\mathrm{N}$ content of 5.4 to 8.8 at. $\%$ in $\mathrm{CN}_{x}$ nanotubes was obtained. The higher $\mathrm{Ni}^{2+}$ content, the higher $\mathrm{N}$ content and proportion of graphitic-like $\mathrm{N}$ structures could be achieved. The tubes grown with $\mathrm{Ni}_{2 \cdot 31} \mathrm{Mg}_{0.08} \mathrm{AlO}_{3.89}$ had larger diameter and an obvious bamboo-like morphology, while an unconspicuous bamboo-like morphology existed in the tubes grown with $\mathrm{Ni}_{1.07}$ $\mathrm{Mg}_{1.01} \mathrm{AlO}_{3.58}$ and $\mathrm{Ni}_{1.99} \mathrm{Mg}_{0.29} \mathrm{AlO}_{3.78}$. In addition, the compartment layers of the tubes grown with $\mathrm{Ni}_{2.31} \mathrm{Mg}_{0.08} \mathrm{AlO}_{3.89}$ were thicker and had a longer distance than those grown with $\mathrm{Ni}_{1.07} \mathrm{Mg}_{1.01} \mathrm{AlO}_{3.58}$ and $\mathrm{Ni}_{1.99} \mathrm{Mg}_{0.29} \mathrm{AlO}_{3.78}$. The present result shows that the control of morphology, $\mathrm{N}$ content and pyridine-like $\mathrm{N}$ structures for $\mathrm{CN}_{x}$ nanotubes can be achieved to a certain extent by varying the content of $\mathrm{Ni}^{2+}$ in $\mathrm{LDH}$ precursors.

\section{Acknowledgements}

This work is conducted with the financial support from the Chinese National '863' (No. 2006AA03Z570) fund and Excellent Young Scholars Research Fund of Beijing Institute of Technology (No. c2007YS0404).

\section{References}

1. Cavani F, Trifiro F and Vaccari A 1991 Catal. Today 11173

2. Zhao Y, Jiao Q Z, Li C H and Liang J 2007 Carbon 452159

3. Odom T W, Huang J L, Kim P and Lieber C M 1998 Nature 39162

4. Fan S, Chapline M G, Franklin N R, Tombler T W, Cassell A M and Dai H 1999 Science 283512

5. Bachtold A, Hadley P, Nakanishi T and Dekker C 2001 Science 2941317

6. Liang W, Bockrath M, Bozovic D, Hafner J H, Tinkham M and Park H 2001 Nature 411665

7. Hamada S, Sawasa S and Oshiyama A 1992 Phys. Rev. lett. 681579

8. Terrones M, Ajayan P M, Banhart F, Blase X, Carrol D L, Charlier J C, Crzerw R, Foley B, Grobert N, Kamalakaran R, Kohler-Redlich P, Ruhle M, Seeger T and Terrones H 2002 Appl. Phys. A74 355

9. Maldonado S, Morin S and Stevenson K J 2006 Carbon 441429

10. Wang X B, Liu Y Q, Zhu D B, Zhang L, Ma H Z, Yao N and Zhang B L 2002 J. Phys. Chem. B106 2186

11. Wang E G, Guo Z G, Ma J, Zhou M M, Pu Y K, Liu S, Zhang G Y and Zhong D Y 2003 Carbon 41827

12. Jang J W and Lee C E 2004 Appl. Phys. Lett. 842877

13. Tao X Y, Zhang X B, Sun F Y, Cheng J P, Liu F and Luo Z Q 2007 Diamond Relat. Mater. 16425

14. Kim N S, Lee Y T, Park J, Han J B, Choi Y S, Choi S Y, Choo J and Lee G H 2003 J. Phys. Chem. B107 9249

15. Choi H C and Park J 2005 J. Phys. Chem. B109 4333

16. Zhao Y, Liang J and Zhou X W $2005 \mathrm{~J}$. Adv. Mater. 3711

17. Liu J W, Webster S and Carroll D L 2005 J. Phys. Chem. B109 15769

18. Shimoyama I, Wu G H, Sekiguchi T and Baba Y 2000 Phys. Rev. B62 R6053

19. Yang Z X, Xia Y D and Mokaya R 2005 Chem. Mater. 174502

20. Lee Y T, Kim N S, Bae S Y and Park J 2003 J. Phys. Chem. B107 12958 